M. Mastny in his letter has injected somewhat unnecessarily the matter of the arbitration of disputes in regard to diplomatic immunities. This is really a separate question, namely, that of the settlement of differences in regard to the interpretation of the rules of international law. Nevertheless it would seem that diplomatic immunities might first be made the object of a general treaty of obligatory arbitration. For important though they be, in that they relate to the question of national dignity, these immunities do not withal involve any great economic interests such as arouse the animosities of the states. Such economic interests, especially those in regard to which the future development and exploitation is somewhat uncertain, can with diffculty be subject to codification by states whose prime consideration seems still to be competition rather than coöperation. This very situation makes it important to take the first step toward codification in regard to a matter like diplomatic immunities, which is not likely to interfere with national designs of aggrandizement.

When the Conference for the Codification of International Law finally assembles, we may expect it to devote its early attention to the matter of diplomatic immunities. The First Hague Conference gave us an outline codification of the adjective law of arbitration. May the forthcoming conference be equally happy in formulating peace-preserving rules to protect the agents of peaceful international intercourse in their peace-intending mission. In this way, more than one unnecessary war may perhaps be avoided in the years to come.

Ellery C. Stowell.

\title{
RESPONSIBILITY OF STATES FOR DAMAGE DONE IN THEIR TERRITORIES TO THE PERSON OR PROPERTY OF FOREIGNERS
}

The subcommittee of the Committee of Experts of the League of Nations which reported on the international responsibility of states $^{1}$ consisted of M. Guerrero, of Salvador, reporter, and M. Wang Chung Hui of China. As the committee states, the report of the subcommittee is based upon one theory of the principles of state responsibility; it is for that reason that the implication or hope that the report may be accepted by all governments as the basis for a convention is likely to be disappointed, though many of the proposed rules merit general acceptance. It is highly desirable that there may be agreement among states on a subject matter which daily occupies their Foreign Offices and which more than most others permits of fairly adequate legal regulation, substantive and procedural.

Before legal regulation is possible, however, there must be some measure of accord on the underlying political theory. The theory suggested by the subcommittee, in the report now under discussion, starts from a major postulate that the foreigner must accept the legal conditions which he finds

1 Printed in Special Supplement to this Journat, July, 1926, pp. 177-203. 
in the country of residence, and that neither he nor his country can justifiably complain if he is accorded, like nationals, the benefit or application of those conditions. The content of those conditions may not be internationally reviewed. Once admit the major premise, and the proposed rules, presently to be discussed, follow more or less naturally by a process of deductive reasoning.

This argument of assimilation and legal equality has been the LatinAmerican thesis for many years. It is embodied in constitutions, in statutes, and to some extent in treaties, and has been promoted by Calvo, Drago, Torres-Caecido, Seijas and others. The writer has indicated his general concurrence in the aspiration of the weaker Latin-American states, his belief that they have often been the victims of the aggressive policies of strong states constituting themselves plaintiff, judge and sheriff at one and the same time, and his disbelief in the opinion entertained in certain Foreign Offices that weak states trade on their weakness to defy the strong. It is the strong and not the weak that most need the curb of law and the cultivation of that self-restraint which is supposed to be the distinguishing mark of civilization.

The following criticism of the report of the subcommittee of the Committee of Experts will therefore not be deemed unsympathetic to the aspiration expressed in the rules proposed. They cannot, however, be entirely endorsed without overlooking some of the facts of legal life in some of the countries of the world and a long continued practice of international courts and Foreign Office procedure establishing what may be called rules of international law. Not that any law is necessarily immutable. Far from it. But before long-established substantive rules should be radically changed, it ought to be shown that the social and other conditions out of which they arose justify the change, or that the underlying political theory is erroneous. This, unfortunately, cannot, it is believed, be shown with respect to the conditions and theories out of which arose the existing rules of international responsibility for injury to aliens.

The report of the subcommittee begins with a short disquisition on the origin of international law and its superiority to national law. It indulges in a fair proportion of the customary legal metaphysics about the "sum total of the will of all nations," the "collective will," the "free consent of states," the "sovereignty" of states and other terms and phrases which becloud clarity of thought. The assertion that the "binding character of international law is founded on the free consent of states" is hardly supportable. States are bound by international law without their consent and in spite of refusal of consent. Witness the numerous decisions and declarations to the effect that no state can by unilateral act defeat or escape its international obligations, e.g., the Russian effort to abolish the system of private property, with respect to foreigners, the attempt of certain Latin-American states to define by municipal legislation the term "denial of justice." It is 
not possible to say categorically how great must be the degree of concurrence in a rule before it may be deemed to have acquired validity as a rule of international law, or how great the degree of disavowal before an existing rule may be deemed to have lost its character as such. But a professed necessity for proving consent of a particular state to a particular rule of customary law would render international law no legal system at all. A new state must, whether it will or not, accept the prevailing rules governing international intercourse, and to the extent that these rules have validity, its so-called "sovereignty" is to that extent limited. Otherwise, the admitted superiority of international law to municipal law, accepted in the report, would be a meaningless maxim.

Yet there was a reason for the report's supposed requirement of unanimous consent, even to a general rule arising out of custom. If the states of Latin-America do not agree to the European definition of denial of justice or to the professed European conditions precedent to diplomatic interposition, the existing practice and law, which reflect European views, are necessarily not to be deemed international law. The way is therefore impliedly open to the establishment of conventional rules in a field not now covered by universally accepted international law.

The premise overlooks the fact, already mentioned, that provable unanimity is not required in general or at a particular occasion to establish a generally accepted rule as binding, even on dissenters, and the additional fact that the local law in a particular community, before foreigners are deemed conclusively bound by it, must meet the standard of civilized justice or international due process of law which custom has developed in international intercourse. The content of the municipal law, which the report deems unreviewable, is therefore at the crux of the legal relations now under discussion. Existing international law maintains-and the report (p. 3) implicitly approves the doctrine-that if the local law falls below the international standard (of due process), the international and not the local rule shall prevail. The benefit of the international rule, however, accrues to foreigners only, and therein lies a source of friction. The machinery of enforcement-by the state of the injured foreigner, without a preliminary judicial decree or judgment-is exceedingly crude, and should be changed in the interests of all parties concerned. But the fact that the prevailing theory adopts a postulate according to which the foreigner is bound by the local law only on condition that the local rule meets the international standard, whereas the report dispenses with any such condition, represents the most noteworthy feature of the report and the principal basis for criticism from the point of view of existing law and practice.

The report makes a considerable point of the issue whether individuals are the subjects of international law or are bound by it. The report concludes that they cannot be. But when one examines the law of contraband, which places the individual under definite duties and liabilities, when one 
notices the convention establishing the Central American Court of Justice and the proposed prize court giving individuals the privilege of suing in the international forum, the answer given by the report, even if it be deemed important, is open to grave doubt. International law and treaties accord rights for the benefit of individuals and impose duties restraining individuals. Possibly the rule advocated in the report (p. 4) to the effect that the individual foreigner can invoke only the state's domestic responsibility and that only a foreign state can invoke its international responsibility, though true, may explain the importance attributed to the theory, for it would perhaps support the validity of the Calvo clause in Latin-American statutes and contracts, by which the alien agrees not to invoke the diplomatic protection of his home government. (See award of the United States-Mexican General Claims Commission, 1926, in case of North American Dredging Company of Texas $v$. Mexico discussed in this Journal, Vol. 20, p. 538, and printed in Judicial Decisions herein, post.)

The report (p. 5) denominates certain rights commonly enjoyed by aliens, such as the right to life, the right to liberty and the right to own property, as transcending in source, authority, and security any national grant. Though using metaphysical phrases, such as "wherever a man goes he takes his rights with him" and that "they belong to the man as a human being" and "are not, accordingly, subordinate to the will of the state," what is meant is that these "rights" are of so elementary a character that any state that should deny them would fall below the international standard of civilized justice or due process of law and would thereby legitimately lay itself open to diplomatic interposition on behalf of the injured alien. The report declares that the enjoyment of these rights involves no guaranty against occasional infringement, but merely an assurance that adequate domestic legal machinery for safeguarding them will be afforded. Yet the foreigner, the report adds, in line with its major postulate, cannot claim a treatment more favorable than is accorded nationals. Here is the major point of difference with the prevailing theory, law and practice. If the local administration of justice breaks down, or if it provides for measures not accepted as "due process," such as holding arrested persons incommunicado, executive or legislative confiscations, etc., international law will demand a treatment for foreigners possibly more favorable than nationals obtain. This has its element of injustice, perhaps, for those who maintain that a foreigner should share the lot of those among whom he resides, whatever it may be. It has, however, compensatory value in exerting an important influence in raising to the international standard the level of administration for everybody. The principal objection lies not in the rule itself, but in its unilateral executive enforcement by strong states, acting as their own judges, and in the fact that weak or disturbed states are often held to a degree of responsibility measured not by their capacity to maintain due process of law but by the principle of insurance. This awakens resentments which are un- 
healthy for the international order, and of course, belies any such maxim as the equality of states, on which the present report (p. 5) lays much stress. The fact is that for some purposes the theoretical equality is conceded, whereas for others it is not. Witness the Covenant of the League of Nations.

Founded on the theory of equality and sovereignty, the report rejects in principle the legitimacy of diplomatic protection. It maintains that the only legal protector of the alien is the state of residence; any interposition by another state would be "trespassing on the sovereignty" of the state of residence, though it later concedes that in a number of cases international responsibility is incurred. This may possibly be reconciled by the presumption, not expressed in the report, that responsibility would be invoked before some judicial forum and never by intervention or perhaps even diplomatic interposition. The report is not altogether clear on these matters.

The means of affording protection to foreigners, according to the report, is also to be left to the state of residence exclusively. Yet it concedes that failure to adopt methods which should have been adopted, or the inadequacy of the methods adopted, would entail responsibility. But the ineffectiveness of the methods adopted would seem, according to the report, to afford no ground for international redress. Foreign states are likely to demand more than the adoption of rules; they also ask their effective enforcement, certainly within the range of capacity, and at least bona fide effort to enforce.

The report adds that the unlawful act or omission of duty must be traceable to the state itself. As a principle this will not be denied. Differences will arise in determining what constitutes unlawfulness, violation of international law or omission of duty, and in this respect the report endeavors, as we shall see, to establish a legislative definition of international duty and "denial of justice" which the United States and European countries have heretofore declined to accept as conclusive when enacted by Latin-American countries. The suggestion that the officer guilty of the unlawful act or omission shall have been acting within the scope of his employment or duty will hardly be denied as proper; but this and the further suggestion that he must be "defending the rights of the State" (p. 8) raise the difficult question of ultra vires, which is treacherous ground in the administrative law of most countries, and which would require clarification before most states would conclude a treaty on the subject.

Territorially responsibility is limited to territory over which the state exercises "sovereignty." "Jurisdiction" might have been a better word, for the report recognizes that occupied territory is not in a position to be defended by or to create responsibility for the ousted state or government. Central federal governments must assume responsibility (p. 6) for the acts of component parts of the federation, and no exception is made for obligations contracted by autonomous states of a federation. Probably an exception for contracts of the latter kind should have been incorporated, for this is in accord with the general Latin-American thesis which the report maintains. 
In dealing with specific types of cases, the report (p. 7) first considers "political crimes committed against foreigners." Here it adopts practically the standard of the special Committee of Jurists, 1924, reporting on the Greek-Italian incident which led to Corfu. Responsibility is incurred, they said, "if the State has neglected to take all reasonable measures for the prevention of the crime and the pursuit, arrest and bringing to justice of the criminal. The recognized public character of a foreigner and the circumstances in which he is present in its territory entail upon a State a corresponding duty of special vigilance on his behalf." The quarrel will not be with the principle. But such words as "reasonable measures," "circumstances," "corresponding duty," "special vigilance," open the field to unlimited debate. The important point is that in the event of an incident, the offended state whose political agents have been injured should not be deemed warranted in determining these debatable questions by gunboats, but that the issues are eminently of a kind requiring judicial examination and construction. To this end, the report (p. 13) recommends in all such cases a commission of inquiry and arbitration, measures which no self-respecting state should be willing to decline. Fortunately the subcommittee had no occasion to approve the extraordinary conclusion of the Corfu committee that a warship could shoot down people in a foreign city without committing an act of war.

In dealing with the responsibility for acts of officials, the report lays down a narrow test of official duty and a broad ultra vires rule which may be difficult to accept. When is an official "defending the rights of the state"? If an official acts within the general scope of his employment, and breaches with respect to aliens the international duty of a state, measured by conformity to local law, international law or treaty, there should be prima facie state responsibility if the act is one of a higher official. This common distinction between higher and minor officials, found in many systems of administrative law and in the decisions of arbitral tribunals, the report does not make. It would hold the state merely to the duty of permitting judicial recourse against the wrong-doing officer, though in fact many states hold the state municipally responsible on the doctrine of respondeat superior. Possibly the reporter would not deny the benefit of such a rule to an injured alien. But to make responsibility for acts of higher officials dependent upon a judicial denial of justice in the pursuit of judicial remedies against them personally, accompanied by an extreme ultra vires doctrine which would almost deny the possibility of a state tort unless "commanded" by the state, is to narrow the scope of responsibility beyond what European nations would probably be willing to accept.

The rule proposed in the report would make practically no difference between an act committed by an official and one committed by a private individual. In either event, state responsibility is predicated upon failure to prevent, after opportunity, an unlawful act, failure to punish for an act 
already committed, or failure to permit judicial recourse. As to private individuals, the rule, as far as it goes, is acceptable; as to public officials, certainly in the higher ranks, it may not be. Perhaps the divergence in the points of view of the "exploiting" and "exploited" states in these matters will prove too wide to bridge by convention, though there is no legitimate reason why this field of action should not be divorced from politics and be regarded as strictly legal.

One of the major chapters of the report (p. 9) is devoted to responsibility for judicial acts. Here the report adopts the view that a state has fully complied with its international duties if it establishes independent courts for the administration of justice. No matter what the decision, even if erroneous and though it misinterpret the law, and though it be "unjust" or "manifestly unjust," foreigners have, according to the proposals of the report, no ground to complain or seek an appeal to the diplomatic or international forum. To do so, is to infringe the "sovereignty" of the state. Only if the state provides no courts, or if it refuses foreigners access to the courts on the same terms with nationals (cautio judicatum solvi excepted?), or if the court refuses to proceed with the case or render a decision, is a "denial of justice" established, entailing international responsibility. The mere rendering of a decision, regardless of its character, refutes the possibility of a "denial of justice.". Delay is not equivalent to a denial of justice.

This is the traditional Latin-American thesis, which European countries and the United States have in principle heretofore refused to accept. As these latter countries more or less demand acceptance for such a doctrine in respect of their own courts, perhaps it is not too much to ask that they concede its application to the countries of Latin-America. As a matter of fact, the principle is conceded in effect to those countries in which the administration of justice invites complete confidence, and no mere "error" or even "unjust" decision will invite interposition. As the weaker countries gradually strengthen the administration of justice, the application of the principle is not likely to be denied them. But it seems unlikely that a mere argument based on the "equality of states" and "sovereignty" will persuade the stronger states to bind themselves to such a definition of "denial of justice." The difficulty here again arises, not so much in a disagreement on the principle, as in its practical application to particular cases, for arbitrariness, discrimination and gross injustice cannot be brought within a definition or a formula. If states would agree to submit unsettled issues of this type to international adjudication and not seek to settle them by political measures, a striking advance will have been made.

With respect to damages caused to foreigners in case of riot and civil war, the rules proposed in the report (p. 11) follow closely those suggested with respect to damage by individuals. They approximate the prevailing general rules and ought to command support. Unless the state has failed, after opportunity, to prevent the riot or failed to punish or endeavor to punish the 
offenders and to afford opportunity for judicial redress, there should be no international responsibility. With respect to civil war, considered a case of force majeure, the state should not be responsible (p. 12) for its own acts in suppressing the rebellion or for those of insurgents beyond its control. The report draws an analogy to losses occurring through strikes. It makes no allowance for negligence in suppressing repellion or the unlawful acts of rebels, a factor in several recent claims conventions, possibly on the ground that such negligence on the part of constituent authorities can rarely, if ever, be inferred. The many cases where responsibility for revolutions has been accepted by certain countries are regarded as exceptions founded on compulsion or other political considerations.

For loss of property sustained by foreigners through the action of the state as a result of requisition, expropriation, confiscation, spoliation or [on] any other arbitrary proceedings "whether in peace, in war or in revolution" the state is deemed internationally responsible (p. 13) and obliged to make compensation. "A state of war or revolution would in no way justify the violation of these rights." If revolutionists commit these acts, the state's responsibility is measured by its failure to perform the duty of providing to foreigners "facilities for prosecuting the offenders and recovering possession of their property." In this connection, it seems almost inconceivable that a highly integrated industrial world and its legal and economic advisers should have tolerated such a demoralizing provision as Article 297 of the Treaty of Versailles confiscating the private property of enemy or ex-enemy nationals. No amount of verbal legerdemain can mitigate its shortsightedness or its dangers as a precedent to all foreigners and foreign investors. Faith in the growing prevalence of law over force and in the security of acquisitions which law is designed to promote, is seriously shaken and impaired by this confiscatory measure, which may charitably be characterized as a regrettable mistake. The sooner it is corrected, the less effective will be its threat to orderly international relations.

The second question covered by the report deals with the possibilities of framing a convention whereby disputed facts giving rise to claims might be definitively established, "and prohibiting in such cases recourse to measures of coercion until all possible means of pacific settlement have been exhausted."

The report proceeds from the assumption, often well-founded, that disputed facts give rise to many claims. Instead of leaving such facts in doubt, with each party drawing its own conclusions on inadequate or biased data, and then acting, sometimes violently, on these conclusions, the report recommends the official adoption of international commissions of inquiry along the lines of the commission provided for at the First Hague Conference. Nothing seems more reasonable than the proposal that doubts and disputes on matters of fact, which could be established by an impartial investigating body, should never be permitted to create international hostility. This 
thought underlies the Bryan treaties, on the basic hypothesis, expressed in the treaties, that if no move looking to hostility were made by either party pending the report of the investigating commission, the healing effect of time and deliberation would have cured the disposition to violence. The same ideas are embodied in the present report. The inadequacy of all such treaties is that they contemplate only particular incidents, and not continuing acts claimed to be lawful by one party and unlawful by the other, where the facts are not in dispute. Yet they serve an important, even if limited function, and should be encouraged. The "cooling" period which the investigation affords doubtless provides an interregnum of great psychological value. The present report proposes that the Permanent Court of International Justice act as intermediary between the states in dispute in arranging for the commission of inquiry, whose function is to be limited to the statement of a conclusion on the facts. It contemplates that the parties would agree to leave to the decision of the Permanent Court any dispute not definitely closed by the report of the commission of inquiry. The states would agree to abstain from all coercive measures until these peaceful means of settlement had been exhausted (p. 16). Here the report makes the same mistake, I believe, that was made in the Porter Proposition at the Second Hague Conference. It sanctions the use of force to collect a certain type of claim, only delaying the authorization to use force until certain measures have been adopted without success. This goes further than both law and customary practice had theretofore sanctioned. Armed force should be by agreement absolutely excluded in the collection of pecuniary claims of any character. That would be an advance toward peace, which presumably the Committee of Experts is designed to promote. Instead of prohibiting force in a field in which its use is now very exceptional only, it actually sanctions the use of force in cases where it is not usually employed. This is hardly a useful contribution.

The report, however learned it is in many respects, may, it is submitted, be deemed to involve even a greater oversight than the one just mentioned. Inasmuch as it proposed to indicate the outlines of a legal code for settling socalled pecuniary claims, mainly in tort, there seems no reason why it should have limited its procedural proposals to the determination of disputed issues of fact. The major objection to the present practice, notably from the Latin-American point of view, is the absence of a peaceful legal procedure for determining issues of law. The present system contemplates the frequent use of political coercion of all types to enforce claims essentially legal in character. Here lay the great opportunity of the subcommittee and of the other international jurists on the committee. The whole field of pecuniary claims, more strictly legal in its nature than many of the other departments of international law, should not only on its substantive, but on its procedural side, be divorced from politics and brought within a legal framework. No pecuniary claim should become the source of coercive political action. Every claim 
should, if not easily settled diplomatically, be submitted by convention, as automatically as possible, to an international court. If this were done, all parties would benefit and such tribunals as the Permanent Court of International Justice would probably never lack a full docket. International law would thus extend its beneficent regulatory power to a field in which politics now unfortunately often reigns supreme. A claimant, having a perfectly legal claim, is now dependent for relief primarily upon the political strength or influence of his nation, on its political relations with the country complained against and on the disposition and willingness of the Foreign Office to exert diplomatic efforts in his behalf. His claim becomes the plaything of politics and of their accidents. The government of the injured citizen is subjected to political pressure to espouse what may be a poor claim, often acts on insufficient evidence, and in prosecuting a claim is led to invoke the support of a whole people on behalf of a single citizen or corporation, a primitive and medieval form of collective revenge which survives in practically no other branch of public law. A people should not be involved in political entanglements arising out of an alleged legal injury to a citizen, if it can possibly be avoided. The defendant nation should not be in the position of having to yield a legal case to political arguments or of availing itself of political strength to resist a legal claim. The cause of peace and normal international relations should not be impaired and hampered by the present easy conversion of a legal into a political issue. An agreement to submit legal pecuniary claims to a legal, i.e., judicial, method of settlement would be one of the greatest boons imaginable not only to the parties and peoples in interest but to a world still delicately balanced between the Scylla of law and the Charybdis of anarchy. In recent years, the forces of lawlessness have made immeasurable gains. Here, in the field of state responsibility for injuries to foreigners, lies a practical opportunity to counteract these demoralizing and disintegrating forces by lifting a most important field of international relations from the arena of politics to the realm of law.

EDWIN M. BORCHARD.

\section{PROCEDURE OF INTERNATIONAL CONFERENCES AND PROCEDURE FOR THE CONCLUSION AND DRAFTING OF TREATIES}

At its second session in January, 1926, the Committee of Experts for the Progressive Codification of International Law decided to submit a questionnaire on the subject of procedure of international conferences and procedure for the conclusion and drafting of treaties to various governments, communicating at the same time a report presented by M. Mastny, and observations on it by M. Rundstein. ${ }^{1}$ The subject comprises two separate topics and it is not clear why they were joined together. The committee

${ }^{1}$ Printed in Special Supplement to this JodrNaL, July, 1926, pp. 204-221. 